\title{
MANAJEMEN DOKUMEN PRODUK BIRO HUKUM DAN HAM SEKRETARIAT DAERAH PROVINSI JAWA BARAT
}

\author{
Yani Kurnia ${ }^{1}$, Sukaesih $^{2}$, Encang Saepudin ${ }^{3}$ \\ ${ }^{1}$ Sekolah Bina Persada Bandung, ${ }^{2,3}$ Program Studi Ilmu Perpustakaan \\ Universitas Padjadjaran \\ 1yanikurnia17@gmail.com, 22 sukesihcicih09@yahoo.com, \\ ${ }^{3}$ encangsaepudin1971@gmail.com
}

\begin{abstract}
The purpose of this research is to understand the activities of the document management of legal products in legal counseling activities at Legal Bureau and Human Rights of Regional Secretariat in West Java Province. The method in this research used qualitative study. Technical data collection conducted through by observation, interviews and literature study. Data analysis technique done with triangulation and based to Miles and Huberman namely data reduction, data display, and conclusion drawing. The result of research showed that the document management of legal products in Legal Bureau and Human Rights following based of documentation from Landau that which recording includes legislation program activities, organization includes processing and storage, and dissemination includes counseling and information disseminated. Based on research results it can be concluded that the document management of legal products in Legal Counseling activities at Legal Bureau and Human Rights Regional Secretariat of West Java Province has been done based to the documentation from Landau.
\end{abstract}

Keywords: Document management, legal products, recording, organization, dissemination.

ABSTRAK - Penelitian ini bertujuan untuk mengetahui kegiatan manajemen dokumen produk hukum dalam kegiatan penyuluhan hukum di Biro Hukum dan HAM Sekretariat Daerah Provinsi Jawa Barat. Metode yang digunakan adalah pendekatan studi penelitian kualitatif. Teknik pengumpulan data dilakukan melalui observasi, wawancara dan studi pustaka. Teknik analisis data dilakukan dengan triangulasi dan teknik analisis data menurut Miles dan Huberman yaitu Data Reduction, Data Display dan Conclusion Drawing. Hasil penelitian menunjukkan bahwa kegiatan manajemen dokumen produk hukum di Biro Hukum dan
HAM Sekretariat Daerah Provinsi Jawa Barat mengikuti kaidah dokumentasi menurut Landau yang mencakup recording yang meliputi kegiatan perumusan, organization yang meliputi kegiatan penyusunan dan penyimpanan serta dissemination yang meliputi kegiatan penyuluhan dan penyebarluasan. Berdasarkan hasil penelitian dapat disimpulkan bahwa manajemen dokumen produk hukum di Biro Hukum dan HAM Sekretariat Daerah Provinsi Jawa Barat telah dilakukan sesuai dengan kaidah dokumentasi menurut Landau.

Kata Kunci: Manajemen dokumen, produk hukum, recording, organization, dissemination.

\section{PENDAHULUAN}

Pembangunan di bidang hukum merupakan bagian yang tidak terpisahkan dari penyelenggaraan pemerintahan yang berprinsif pada tata kelola pemerintahan yang baik dan bersih. Hukum dibuat untuk membuat tatanan kehidupan menjadi lebih tertib, tentram dan teratur. Untuk menciptakan masyarakat yang taat hukum, maka penyebaran informasi hukum yang merata perlu dilakukan oleh pemerintah.

Mengingat pentingnya informasi hukum maka perlu dilakukan pendokumentasian terhadap dokumen-dokumen produk hukum atau perundang-undangan. Hal ini dimaksudkan untuk memecahkan berbagai kasus hukum ataupun 
menjadi batasan, aturan kehidupan bermasyarakat yang tidak boleh dilanggar sehingga supremasi hukum bisa ditegakkan.

Dokumen produk hukum merupakan kumpulan aturan peraturan perundang- undangan yang menjadi titik tolak semua kegiatan negara dan masyarakat. Dokumen-dokumen itu sendiri perlu dikelola dengan baik agar bisa dimanfaatkan sesuai dengan kebutuhan. Hal ini biasa disebut dengan sistem manajemen dokumen. Sistem manajemen dokumen merupakan pengelolaan dokumen yang dikembangkan untuk mengatur dan mengelola dokumen-dokumen penting agar mudah untuk dicari dan ditemukan kembali. Dimanfaatkan sebagai efektivitas dan efisiensi serta kepentingan lembaga.

Sesuai dengan Keputusan Presiden Nomor 44 tahun 1974 tentang Pokok-Pokok Organisasi Departemen serta Keputusan Presiden Nomor 45 Tentang Susunan Organisasi Departemen disebutkan bahwa perlu ada pembentukan Badan Penelitian dan Pengembangan (Litbang) pada setiap departemen yang didalamnya memiliki pusat dokumentasi dan perpustakaan yang disesuaikan pada instansi masing-masing. Keberadaan unit ini sangat berguna dan berperan penting dalam pertimbangan pengambilan keputusan, pembuatan kebijakan, dan sumber informasi demi mencapai tujuan dan kepentingan instansi atau lembaga tersebut. Dan ada pula kewajiban Pemerintah Daerah untuk melakukan penyebarluasan peraturan perundang-undangan yang diatur dalam UU RI Nomor 23 Tahun 2014 tentang Pemerintah Daerah bagian keempat pasal
254 bahwa Kepala Daerah melalui Sekretaris Daerah wajib menyebarluaskan Peraturan Daerah untuk memberikan informasi dan memperolehnya.

Menanggapi peraturan perundang-undangan diatas maka, di Biro Hukum dan HAM terdapat bagian Dokumentasi dan Penyuluhan Hukum dimana bagian ini bertanggungjawab untuk mengelola dokumen produk hukum dan penyebarannya kepada masyarakat. Untuk manajemen dokumen produk hukum, mereka memakai sistem yang sesuai dengan keilmuan kepustakaan. Dokumen produk hukum yang dimiliki biro ini sudah dalam bentuk dokumen buku (dibukukan), dihimpun perbidang atau peraspek hukumnya. Sedangkan penyuluhan hukum dilakukan melalui sosialisasi, pembinaan, dan pelatihan hukum serta penyebaran dokumen produk hukum yang dilakukan rutin setiap tahun yang sumbernya berasal dari dokumen-dokumen yang telah dikelola di bagian dokumentasi.

Kegiatan penyuluhan hukum sendiri merupakan bentuk penyebaran informasi hukum yang sangat erat dengan proses suatu informasi dikomunikasikan melalui saluran tertentu dalam jangka waktu tertentu. Dimana informasi hukum yang dikomunikasikan atau yang disebarluaskan tersebut nantinya dapat meningkat pengetahuan masyarakat terhadap hukum. Bahkan meningkatkan kesiapan masyarakat dalam menghadapi perubahan menuju masyarakat yang taat dan sadar hukum. Maka dalam setiap kegiatan penyuluhan harus ada pula kegiatan dokumentasi untuk produk hukum yang akan 
disebarluaskan melalui kegiatan penyuluhan hukum.

Penyuluhan hukum bertujuan untuk mewujudkan kesadaran hukum masyarakat yang lebih baik sehingga setiap anggota masyarakat menyadari dan menghayati hak dan kewajibannya. Dengan demikian akan terwujud budaya hukum dalam sikap dan perilaku yang sadar, patuh, dan taat terhadap hukum demi tegaknya supremasi hukum. Eksistensi penyuluhan hukum ditingkatkan sejalan dengan dinamikamasyarakat dan kemajuan teknologi karena penyuluhan hukum bukan hanya sematamata menyampaikan informasi hukum tetapi juga hal-hal yang tidak terbaca dari peraturan perundang-undangan. Penyuluhan hukum diharapkan dapat memotivasi masyarakat agar lebih tanggap terhadap perkembangan dan dinamika hukum dengan berpartisipasi aktif dalam mewujudkan budaya hukum di tengah masyarakat.

Untuk dapat mendukung suksesnya kegiatan penyuluhan hukum, maka tentunya keadaan manajemen dokumen hukum tentu harus dikelola sesuai dengan standar dokumentasi yang baik. Agar mudah dicari, ditemukan kembali secara cepat, mudah, baik dan efesien bilamana dibutuhkan. Terutama sebagai sumber dan materi utama bagi kegiatan penyuluhan hukum. Adapun capaian dari penelitian ini adalah:

1. Untuk mengetahui recording dokumen produk hukum di Biro Hukum dan HAM Sekteratiat Daerah Provinsi Jawa Barat
2. Untuk mengetahui organization dokumen produk hukum di Biro Hukum dan HAM Sekteratiat Daerah Provinsi Jawa Barat

3. Untuk mengetahui dissemination dokumen produk hukum melalui kegiatan penyuluhan hukum di Biro Hukum dan HAM Sekteratiat Daerah Provinsi Jawa Barat.

\section{TINJAUAN PUSTAKA}

Penelitian ini berangkat dari studi dokumentasi menurut Thomas Landau dalam Encyclopedia of Librarianship yang diterbitkan ASLIB dalam Journal of Documentation mengemukakan bahwa dokumentasi adalah "recording, organization, and dissemination of specialized knowledge" khususnya dalam rangka pembinaan dan pengembangan koleksi pusat dokumentasi suatu organisasi (Landau, 1968). Ditambah dengan proses penyebaran atau difusi informasi merupakan kajian strategis dalam ilmu media dan komunikasi karena proses difusi yang berhasil akan mampu memberikan multiplaying effect yang signifikan.

Penyebaran informasi atau difusi informasi merupakan proses dimana suatu informasi atau inovasi dikomunikasikan melalui saluran tertentu dalam jangka waktu tertentu di antara para anggota suatu sistem sosial (Rogers, 2003). Teori ini menekankan proses komunikasi, baik yang menyangkut informasi yang dibutuhkan untuk memiliki dan menerapkan inovasi maupun pesan yang direncanakan untuk meningkatkan pengetahuan masyarakat akan sesuatu hal. Sehingga meningkatkan kesiapan masyarakat 
dalam menghadapi perubahan. Berikut kerangka penelitian yang dapat digambarkan untuk memudahkan peneliti dalam melakukan penelitian adaptasi dan modifikasi dari sumber dan hasil pengamatan penulis 2015 .

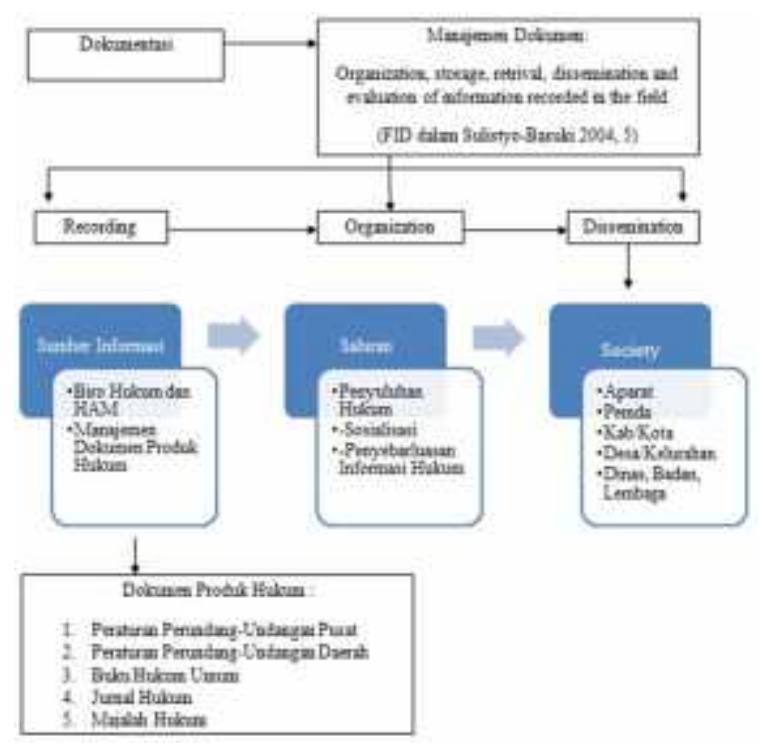

Gambar 1. Kerangka hasil penelitian

Sumber: Analisis hasil penelitian

Secara teoritis melalui penelitian ini diharapkan bisa memberikan manfaat serta informasi untuk perkembangan penerapan keilmuan Ilmu Informasi dan Perpustakaan terutama di bidang pendokumentasian (dokumentasi), manajemen dokumen, dan penyebaran informasi yang diterapkan melalui kegiatan pendokumentasian dan penyuluhan dokumen produk hukum.

Melalui penelitian ini secara praktis diharapkan bisa memberikan manfaat serta bahan masukan dan pertimbangan bagi Biro Hukum dan HAM Setda Provinsi Jawa Barat dalam menelaah dan memahami secara objektif mengenai bagaimana kegiatan pendokumentasian yang efektif terhadap produk mereka dan dapat dipahami oleh semua staf untuk memberikan manfaat untuk pekerjaan mereka dengan bantuan pendokumentasian yang dilakukan terhadap produk hukum serta penyebarluasannya kepada masyarakat. Sebagai bahan referensi dan dapat menambah pembendaharaan informasi seputar kegiatan pendokumentasian dan penyebarluasan informasi hukum bagi yang membutuhkan. Dapat menambah wawasan ilmu pengetahuan terutama dibidang manajemen dokumen dan pendokumentasian terhadap dokumen-dokumen penting serta mengetahui bagaimana pentingnya pendokumentasian, bagaimana manfaat dan penyebarluasannya. Dapat juga menjadi masukan dan referensi bagi peneliti lainnya dalam penelitian yang serupa.

\section{METODE PENELITIAN}

Permasalahan yang akan dikaji dalam penelitian ini adalah mengenai "Studi Kualitatif mengenai Manajemen Dokumen Produk Hukum Dalam Kegiatan Penyuluhan Hukum Biro Hukum dan HAM Sekretariat Daerah Provinsi Jawa Barat" dalam menyebarluasan peraturan perundang-undangan atau memberikan informasi hukum melalui kegiatan penyuluhan hukum. Penelitian ini meneliti tentang bagaimana pelaksanaan manajemen dokumen produk hukum di Biro Hukum dan HAM Setda Jabar dalam menata dan menyebarluaskan dokumen produk hukum kepada masyarakat. Biro Hukum dan HAM Setda Jabar sendiri menurut Peraturan Gubernur Jawa Barat Nomor 29 Tahun 2009 mempunyai tugas pokok menyelenggarakan perumusan bahan kebijakan umum dan koordinasi, fasilitasi, pelaporan serta evaluasi di 
bidang perundang-undangan, dokumentasi dan penyuluhan hukum, fasilitasi produk hukum Kabupaten/Kota serta bantuan hukum dan Hak Asasi Manusia (Biro Hukum dan HAM Sekretariat Daerah Pemerintahan Provinsi Jawa Barat, 2015).

Tujuan dari penelitian ini adalah untuk mengetahui recording dokumen produk hukum di Biro Hukum dan HAM Sekteratiat Daerah Provinsi Jawa Barat, organization dokumen produk hukum di Biro Hukum dan HAM Sekteratiat Daerah Provinsi Jawa Barat, dissemination dokumen produk hukum melalui kegiatan penyuluhan hukum di Biro Hukum dan HAM Sekteratiat Daerah Provinsi Jawa Barat. Penelitian ini dilakukan secara kualitatif, yaitu untuk mengamati proses kegiatan objek yang akan diteliti. Disebut juga metode artistik karena proses penelitiannya lebih bersifat seni (kurang berpola) dan disebut sebagai metode interpretif karena data hasil penelitian lebih berkenaan dengan interprestasi terhadap data yang ditemukan di lapangan. Penetian kualitatif ini dijabarkan secara deskriptif (kualitatif deskriptif). Memahami fenomena dan mendeskripsikannya kedalam kontek ilmiah yang dapat dipahami secara mendalam (Sugiyono, 2013).

Pada penelitian ini, peneliti mengamati proses seperti yang dijelaskan diatas tentang cara kerja penelitian kualitatif. Proses yang diamati peneliti di Biro Hukum dan HAM yaitu fokus kepada proses dokumentasi dan penyebaran informasi hukum. Pengamatan dilakukan secara interaktif didukung dengan data dan dokumen yang didapatkan selama dilapangan. Dari fakta- fakta yang ada dilapangan, peneliti mengidentifikasinya dengan hipotesis, kerangka konsep pemikiran yang dibuat dianalisa apakah relevan. Mengulik hal-hal unik selama proses dokumentasi dan penyebaran informasi di Biro Hukum dan HAM Sekda Jabar. Teknik pengumpulan data dalam penelitian ini dilakukan melalui observasi, wawancara, dan studi pustaka. Observasi dilakukan beberapakali untuk mengamati secara langsung dilapangan bagaimana cara kerja yang diberlakukan terhadap dokumen produk hukum di Biro Hukum dan HAM Setda Jabar.

Sedangkan untuk wawancara dilakukan secara interaktif kepada empat (4) informan dimana semua informan tersebut adalah pihak yang terlibat langsung dengan Biro Hukum dan HAM Setda Jabar. Melalui beberapa pertimbangan, yang menjadi informan dalam penelitian ini adalah (1). Rosmah Dewi Asmarani, beliau adalah kepala Bagian Dokumentasi dan Penyuluhan Hukum, Biro Hukum dan HAM Sekda Jabar. Sesuai dengan jabatan beliau, peneliti menyiapkan daftar wawancara yang pertanyaannya lebih bersifat umum. Mengenai aktivitas dan program bagian yang beliau kepalai. (2). Supriadi, beliau adalah kepala Sub bagian Dokumentasi Hukum. Karena pekerjaan beliau lebih ke teknik langsung dilapangan, maka peneliti menyiapkan daftar pertanyaan yang lebih rinci terkait dengan proses manajemen dokumen produk hukum. (3). Aan Fardiah, beliau adalah kepala Subbagian Penyuluhan Hukum. Daftar pertanyaan yang peneliti siapkan untuk wawancara dengan beliau 
seputar rincian kegiatan dilapangan terkait dengan kegiatan penyuluhan hukum yang diselenggarakan. (4). Engkus Kusnadi, beliau adalah kepala Sub Bagian Penyusunan Perda. Wawancara dari beliau peneliti memperoleh informasi mengenai perumusan perda karena beliau berwenang dalam pelaksanaan perumusan dan penyusunan perda.

Untuk menguji keabsahan data, maka peneliti juga melakukan wawancara triangulasi dengan pihak akademisi Bapak Rohanda. Beliau adalah kepala UPT Perpustakaan Universitas Padjadjaran (CISRAL) dan juga merupakan salah satu staf dosen pengajar di Depertemen Ilmu Informasi dan Perpustakaan Fakultas Ilmu Komunikasi Universitas Padjadjaran. Peneliti sengaja melakukan wawancara dengan beliau untuk memperoleh informasi pembanding (triangulasi), kebenaran serta klarifikasi bidang manajemen dokumen sesuai dengan keilmuan dan kajian ilmu informasi dan perpustakaan. Sehingga dari hasil wawancara dengan beliau, peneliti bisa melakukan identifikasi, analisis data hasil penelitian secara lebih tepat sesuai dengan kajian ilmiah ilmu informasi dan perpustakaan. Serta triangulasi dari Ibu Sri Rakhmiyati, beliau adalah sekretaris Perpustakaan Mochtar Kusumaatmadja Fakultas Hukum Universitas Padjadjaran. Peneliti memilih beliau sebagai narasumber (praktisi) untuk triangulasi dalam penelitian ini dengan alasan karena beliau adalah pengelola perpustakaan Fakultas Hukum.

Secara teknis, pengelolaan dokumen produk hukum di Biro Hukum dan HAM Setda Jabar sama dengan pengelolaan perpustakaan pada umumnya. Maka dari ini peneliti melakukan wawancara triangulasi dengan ibu Sri karena yang beliau kerjakan pada dasarnya sama dengan yang dilakukan di Biro Hukum dan HAM, hanya saja item atau objek yang dikelola saja yang berbeda.

\section{HASIL DAN PEMBAHASAN}

Kegiatan manajemen dokumen produk hukum di Biro Hukum dan HAM Setda Jabar meliputi beberapa tahapan mulai dari dirancangnya peraturan perundang-undangan sampai peraturan perundang-undangan tersebut ditetapkan dan disebarluaskan kepada masyarakat dan aparat pemerintahan Provinsi Jawa Barat. Tahapan itu meliputi: perundang-undangan, dokumentasi produk hukum dan Penyuluhan hukum. Pada tahap perumusan atau pembentukan peraturan perundang-undangan dimana dalam penelitian ini peneliti memaparkan tahap demi tahap yang dilakukan dalam proses perumusan PERDA (Peraturan Daerah).

Proses pembentukan PERDA mencakup tahapan perencanaan, penyusunan, pembahasan, pengesahan atau penetapan, dan pengundangan. Proses pelaksanaan ini memang harus sesuai dengan yang telah tercantum dalam UndangUndang Nomor 12 Tahun 2011 tentang Pembentukan Peraturan Perundang-Undangan.

$\begin{array}{lr}\text { "Pembentukan Peraturan } & \text { Perundang- } \\ \text { undangan adalah pembuatan } & \begin{array}{r}\text { Peraturan } \\ \text { mencakup }\end{array} \\ \text { Perundang-undangan yang } & \begin{array}{r}\text { mencunan, } \\ \text { tahapan perencanaan, }\end{array} \text { penyusunan } \\ \text { pembahasan, pengesahan atau penetapan, dan } \\ \text { pengundangan. Peraturan Perundang- } \\ \text { undangan adalah peraturan tertulis yang } \\ \text { memuat norma hukum yang mengikat secara } \\ \text { umum dan dibentuk atau ditetapkan oleh }\end{array}$


lembaga negara atau pejabat yang berwenang melalui prosedur yang ditetapkan dalam Peraturan Perundang-undangan" (Biro Hukum dan HAM Sekretariat Daerah Pemerintahan Provinsi Jawa Barat, 2015).

Berikut alur yang dapat digambarkan dari proses perumusan peraturan perundangundangan menurut hasil wawancara dengan (Kusnadi, 2015).

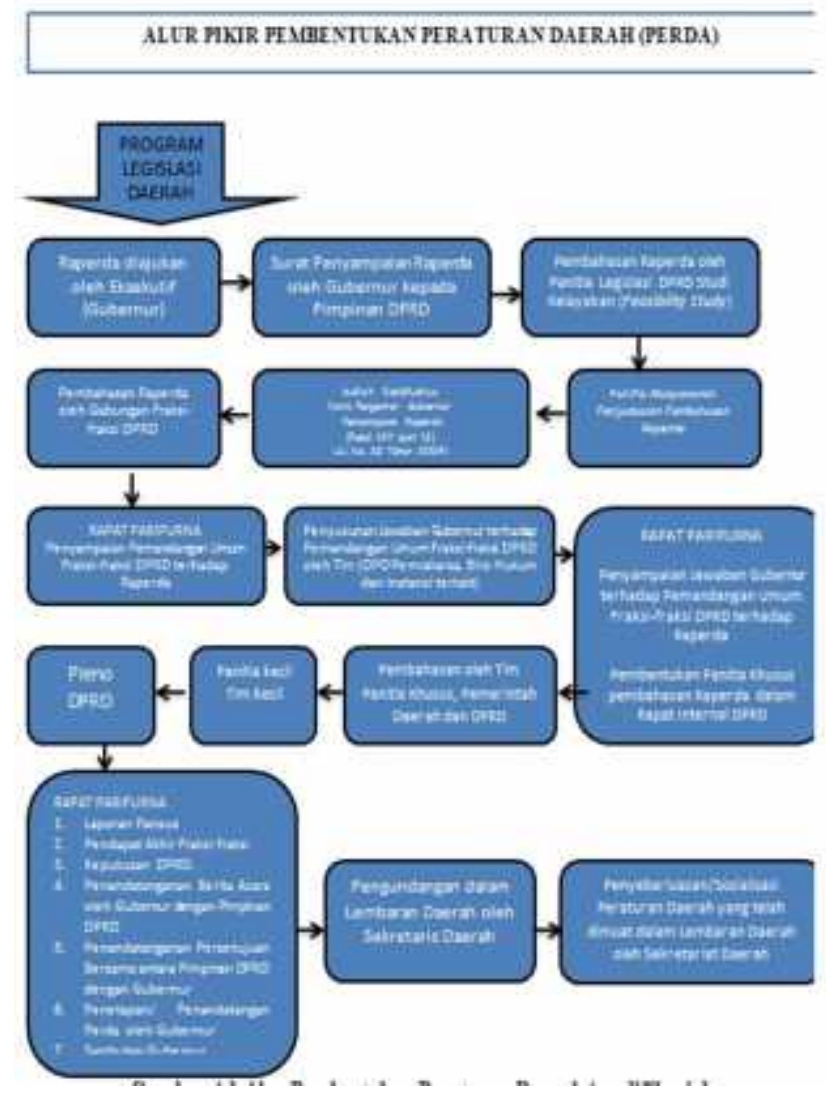

Gambar 2. Alur Pembentukan PERDA

Sumber: Analisis Hasil Penelitian

Berdasarkan pengamatan di lapangan, wawancara dan observasi, peneliti menilai bahwa proses perumusan perundang-undangan yang dilakukan disesuaikan dengan ketentuanketentuan yang dimuat dalam UU Nonor 12 Tahun 2011 tentang Pembentukan Peraturan Perundang- undangan dan Peraturan Menteri Dalam Negeri Nomor 1 Tahun 2014 tentang Pembentukan Produk Hukum Daerah. Dua dasar hukum ini menjadi alasan mutlak yang harus dilaksanakan oleh Pemerintah Daerah dalam merumuskan pearaturan daerah.

"Untuk pelaksanaan perumusan peraturan perundang-undangan daerah harus sesuai dengan dua dasar hukum diatas mengingat dokumen hukum adalah dokumen resmi, penting dan sangat berpengaruh luas di masyarakat. Dasar hukum yang ada untuk perumusan perundang-undangan harus dipatuhi dan dilaksanakan dengan sebaikbaiknya agar dokumen hukum yang dihasilkan setelah ketuk palu tidak memiliki cacat hukum sama sekali" (Jaringan Dokumentasi dan Informasi Hukum Pemerintahan Provinsi Jawa Barat, 2015).

Tahap pengorganisasian dokumen produk hukum yang di dokumentasikan di sub bagian dokumentasi hukum dilakukan menurut kaidah perpustakaan. Pengorganisasian ini bertujuan untuk penataan dokumen produk hukum secara sitematis menurut kaidah dokumentasi dan perpustakaan, dikelola, disimpan dan dimanfaatkan untuk kepentingan lembaga. Hasil dari wawancara peneliti dengan narasumber Supriadi, Kepala Sub Bagian Dokumentasi Hukum menyatakan bahwa,

"Dalam tahapan dokumentasi dokumen produk hukum, Biro Hukum dan HAM Sekda Jabar berfokus pada penyelenggaraan penataan dan penyusunan peraturan perundang-undangan (Pengorganisasian Dokumen)" (Supriadi, 2015).

Dokumen produk hukum yang masuk ke Biro Hukum dan HAM Setda Jabar dikelola di sub bagian ini. Sumber dokumen terbagi menjadi dua, yaitu internal dan eksternal. Dokumen internal adalah dokumen yang memang sudah ada hasil perumusan sampai diketuk palu 
(peraturan perundang-undangan daerah). Dokumen eksternal adalah dokumen yang diperoleh dari instansi lain dan dokumen pembelian yang terhadapnya dilakukan akuisisi.

Jenis dokumen digolongkan ke dalam dua kategori, pusat dan daerah. Ada juga dokumen lain seperti buku hukum umum, majalah, jurnal dan koran. SOP alur masuk dokumen produk hukum (pusat dan daerah termasuk didalamnya PERDA dan jenis perundang-undangan lainnya) ke Biro Hukum dan HAM Setda Jabar terlebih dahulu dilakukan klarifikasi/pengecekan terhadap dokumen apakah sudah sesuai dengan yang seharusnya. Kemudian dokumen dinomori menurut tata naskah dan diberi cap. Terdapat dokumen/koleksi cetak dan digital. Dokumen yang berbentuk digital/softcopy di kelola dalam satu komputer, disusun secara sistematis menurut tahun dan nomor perundang-undangan ke dalam folder-folder dengan ekstention PDF. Softcopy dari dokumen produk hukum ini nantinya juga di input kedalam website JDIH Pemprov Jabar sebagai bentuk penyebarluasan melalui media massa kepada masyarakat.

JDIH adalah jaringan dokumentasi dan informasi hukum dimana semua kabupaten/kota se jabar menjadi anggota jaringannya. Melalui website JDIH ini semua Kabupaten/Kota dapat menginput secara mandiri dokumen produk hukumnya sendiri dalam bentuk PDF dimana nantinya masyarakat dapat mengakses dan mendownload dokumen tersebut secara online dan gratis. Sedangkan bagi dokumen tercetak yang masuk ke Biro Hukum dan HAM Setda Jabar, setelah pemberian nomor dan cap dilakukan, selanjutnya dokumen tersebut di registrasikan (pencatatan identitas dokumen) dimana datanya diinput kedalam website JDIH (dulu menggunakan Software DOLPHIN, sekarang dialihkan ke website JDIH). Input data meliputi keterangan nomor identitas, judul perundang-undangan, tahun terbit, kota terbit, lembaga yang menerbitkan, subjek, nomor klasifikasi (klasifikasi menggunakan UDC), nomor ISBN, jenis perundang- undangan, sumber pengadaan, edisi, jilid, dan jumlah eksemplar. Setelah itu dilakukan proses pelabelan. Warna label dibedakan berdasarkan jenis perundangundangan. Warna hijau untuk dokumen produk hukum yang pusat, biru untuk perda, dan kuning untuk pergub. Cetak label dilakukan secara otomatis dari website JDIH.

Label dicetak menggunakan kertas stiker ditempel pada punggung buku sebelah bawah. Tahap selanjutnya dalam pengorganisasian dokumen cetak adalah penyimpanan. Proses penyimpanan diantaranya meliputi penjajaran buku pad arak dan lemari penyimpanan. Penjajaran dilakukan sesuai warna label dan nomor kelas dokumen. Sistem penataan dokumen memang dilakukan melalui website JDIH oleh admin atau staf pengelola (Jaringan Dokumentasi dan Informasi Hukum Pemerintahan Provinsi Jawa Barat, 2015). Namun masyarakat yang membuka website ini hanya bisa mengakses berita-berita dan PDF dari dokumen hukum yang di inputkan admin kedalamnya. Sedangkan untuk data dokumen cetak (buku-buku) tidak bisa diakses masyarakat karena tidak ditampilkan bagi pengguna website. Yang bisa menelusur semua 
buku/dokumen yang diinputkan kedalam sistem ini hanya orang dalam dari Biro Hukum dan HAM Setda Jabar saja (sistem tertutup). Tahap penyebarluasan dokumen produk hukum dan informasi hukum di Biro Hukum dan HAM Setda Jabar di lakukan di 27 Kabupaten/Kota se- Jawa Barat dengan dibagi ke dalam 4 (empat) wilayah koordinasi.

Tabel 1. Pembagian Wilayah Badan Kooordinasi Jawa Barat

\begin{tabular}{|c|c|c|c|}
\hline \multicolumn{4}{|c|}{ 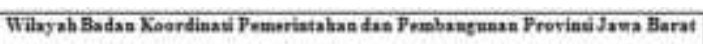 } \\
\hline T & II & III & N \\
\hline 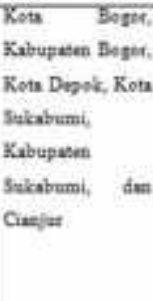 & 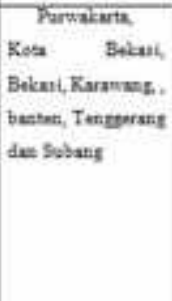 & 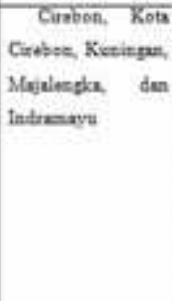 & 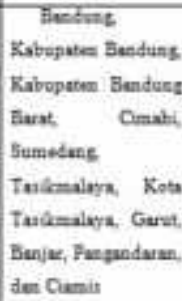 \\
\hline
\end{tabular}

Sumber (Jaringan Dokumentasi dan Informasi

Hukum Pemerintahan Provinsi Jawa Barat, 2015)

Penyebarluasan dilakukan oleh Sub Bagian Penyuluhan Hukum dengan dua bentuk kegiatan.

Kegiatan penyebaran langsung dan tidak langsung. Kegiatan lansung itu meliputi sosialisasi dengan langsung turun ke daerahdaerah. Aan Fardiah, selaku Kepala Subbagian Penyuluhan Hukum menyatakan dalam wawancara pada 3 Maret 2015 dikantornya bahwa:

"Kegiatan sosialisasi peraturan perundang-undangan dimaksudkan agar aparat dan masyarakat Jawa Barat mengetahui, mengerti dan memahami peraturan perundang-undangan sehingga peraturan tersebut dapat dilaksanakan dan diharapkan dapat diinformasikan pula ke masyarakat disekitarnya. Bukan hanya sekedar membaca yang tertulis pada perundang-undangan, tetapi juga memahami isi yang terkandung didalamnya dan mempraktekkan dalam kehidupan sehari-hari” (Fardiah, 2015 ).

Selain sosialisasi juga ada pelatihan (Bintek dll.) dan pembinaan desa sadar hukum. Kegiatankegiatan ini diselenggarakan rutin setiap tahunnya dengan Biro Hukum dan HAM Setda Jabar sebagai penyelenggara bekerjasama dengan instansi terkait. Sedangkan kegiatan penyebaran tidak langsung dilakukan melalui penyebaran dokumen produk hukum ke setiap Kabupaten/Kota (pengiriman dokumen) dan penyebaran melalui website JDIH. Segmentasi dari penyebarannya adalah semua aparatur daerah Kabupaten/Kota dan masyarakat Provinsi Jawa Barat. Penyebarluasan ini tujuan utamanya agar masyarakat tahu hukum, paham hukum, sadar hukum, untuk kemudian patuh pada hukum tanpa paksaan, tetapi menjadikannya sebagai suatu kebutuhan.

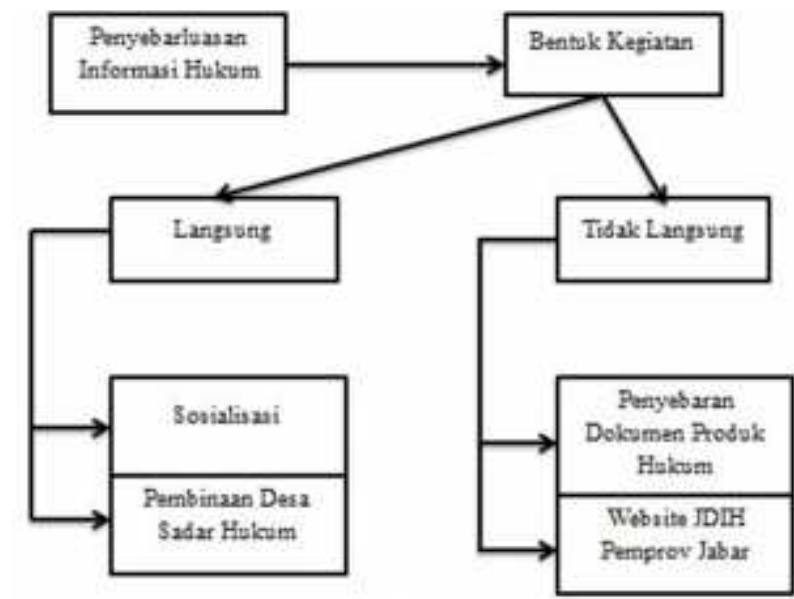

Gambar 3. Kegiatan penyebarluasan

Sumber: Analisis hasil penelitian

Secara menyeluruh berdasarkan hasil pengamatan dilapangan serta wawancara dengan informan, pengelolaan manajemen dokumen produk hukum di Biro Hukum dan HAM Setda Jabar masih dikategorikan tahap awal, belum sempurna dan perlu ada peningkatan dan evaluasi 
dibeberapa aspek. Dalam wawancara triangulasi yang dilakukan peneliti dengan akademisi, Rohanda mengatakan bahwa:

"Manajemen untuk pengelolaan dokumen/koleksi yang baik itu harus baik dalam empat aspek, yaitu planning, organization, aquition, dan controlling. Manajemen dokumen dikatakan efektif apabila perencanaan, penyusunan, penyimpanan dan penyedian alat akses untuk dokumen terpenuhi” (Rohanda, 2015).

Mengacu kepada kegiatan pendokumentasian dokumen produk hukum yang ada di Biro Hukum dan HAM Setda Jabar, mereka telah memiliki perencanaan yang baik. Terbukti dengan terpenuhinya kebutuhan bagian lain seperti sub bagian penyuluhan hukum dalam kegiatannya karena adanya dokumentasi. Disini keberadaan sub bagian dokumentasi sangat penting bagi sub bagian penyuluhan untuk sumber informasi dan materi untuk penyuluhan dan penyebaran peraturan perundang-undangan.

Bukan hanya bagi sub bagian penyuluhan hukum, tetapi juga bagi sub bagian lainya di Biro Hukum dan HAM. Untuk pengelolaan/pengorganisasian sebuah unit dokumentasi, Rohanda juga menambahkan bahwa : "Penilaian manajemen dokumen yang baik dilihat dari bagaimana keadaan pengelolaan koleksi/dokumen yang dikelola, perangkat (sarana dan prasarana) dan keadaan sumber daya manusianya serta anggaran biaya operasionalnya" (Rohanda, 2015).

Untuk sumber daya manusia dalam pengelolaan dokumen di Biro Hukum dan HAM Setda Jabar saat ini bukanlah staf yang ahli, bukan berlatar pendidikan ilmu dokumentasi dan perpustakan. Menurut Sri Rakhmiyati, Sekretaris Perpustakaan Mochtar Kusumaatmadja Fakultas Hukum Unpad, menyatakan bahwa :

"Mereka yang bekerja di bidang dokumentasi dan manajemen dokumen/koleksi harus benar-benar paham misalnya mulai dari menentukan subjek kemudian klasifikasinya. Begitu juga dengan mereka yang ditugasi dengan operasional perangkat pengelolaan seperti komputer atau sistem alat bantu pencarian untuk pengelolaannya. Dan seseorang yang memasukkan data kesitu seharusnya memang sudah paham misalnya satu buku ini masuknya kemana. Terlebih lagi berbicara masalah dokumen hukum. Dalam satu buku hukum itu biasanya terdapat variasi perundang-undangan didalamnya. Maka petugas pengelolaannya harus bisa mempertimbangkan subjek dan nomor kelas yang tepat bagi dokumen tersebut" (Rakhmiyati, 2015).

\section{SIMPULAN}

Dari keseluruhan pembahasan dapat disimpulkan bahwa:

1. Aktivitas Recording manajemen dokumen produk hukum adalah perumusan peraturan perundangundangan yang meliputi perencanaan, penyusunan, pembahasan, pengesahan atau penetapan, dan pengundangan. Pelaksanaan perumusan dilakukan berdasarkan dasar hukum pembentukan peraturan perundang-undangan yang menjadi sadar mutlak pelaksanaan perumusan. Hasil akhir dari perumusan yang telah diketuk palu dibuatkan dalam softcopy dan hardcopy yang selanjutnya akan diorganisasikan di bagian dokumentasi 
2. Aktivitas Organization atau pengorganisasian dokumen produk hukum di Biro Hukum dan HAM Setda Jabar merupakan kegiatan dokumentasi yang meliputi pendataan setiap dokumen yang masuk, kemudian dikatalogisasi, diberi nomor kelas menurut UDC lalu diberi label. Sumber dokumen berasal dari internal dan eksternal. Dokumen internal adalah dokumen yang memang sudah ada hasil dari perumusan berupa dokumen prosuk hukum daerah. Dokumen eksternal adalah dokumen yang diperoleh dari instansi lain berupa dokumen produk hukum pusat dan dokumen lain dari hasil pengadaan (pembelian, sumbangan, hadiah). Penyimpanan dan penataan untuk dokumen produk hukum dilakukan berdasarkan warna label dan nomor kelas. Kegiatan input data dilakukan ke dalam sistem JDIH. JDIH adalah Jaringan Dokumentasi dan Informasi Hukum yang berupa website untuk penyebaran dokumen produk hukum secara online dan juga berfungsi sebagai alat bantu pencarian

3. Aktivitas Dissemination atau penyebarluasan dilakukan melalui kegiatan penyuluhan hukum dalam dua bentuk, secara langsung berupa sosialisasi, pelatihan dan pembinaan dan secara tidak langsung berupa penyebaran dokumen produk hukum secara konvensional (pengiriman dokumen) dan melalui website JDIH. Segmentasi penyebaran adalah para aparatur dan masyarakat Provinsi Jawa Barat. Penyebarluasan informasi hukum memanfaatkan dokumen yang berpotensi yang telah dikelola di bagian dokumentasi dan juga sumber-sumber informasi lain seperti dari instansi-instansi yang diajak bekerja sama untuk menjadi narasumber atau partner dalam kegiatan penyuluhan.

\section{DAFTAR PUSTAKA}

Biro Hukum dan HAM Sekretariat Daerah Pemerintahan Provinsi Jawa Barat. (2015). Retrieved from http://birohukum.jabarprov.go.id/

Jaringan Dokumentasi dan Informasi Hukum Pemerintahan Provinsi Jawa Barat. (2015). Retrieved from http://jdih.jabarprov.go.id/

Fardiah, A. (2015, Maret 3 ). Kegiatan Penyebaran Langsung. (Y. Kurnia, Interviewer)

Kusnadi, E. (2015, Maret 27). Perumusan Perundang-undangan. (Y. Kurnia, Interviewer)

Landau, T. (1968). Encyclopedia ofLibrarianship . A SLIB Journal of Documentation.

Rakhmiyati, S. (2015, April 23 ). Sumber Daya Manusia dalam Pengelolaan Dokumen. (Y. Kurnia, Interviewer)

Rogers, E. M. (2003). Diffusion of Innovations. New York : Free Press.

Rohanda. (2015, April 23). Pengelolaan Manajemen Produk Hukum. (Y. Kurnia, Interviewer)

Sugiyono. (2013). Metode Penelitian Kuantitatif Kualitatif dan R\&D. Bandung : AlfabetA.

Supriadi. (2015, Maret 27). (Y. Kurnia, Interviewer) 
